DIANA BOŽıć, Ph.D.

E-mail: diana.bozic@fpz.hr

RATKO STANKOVIĆ, Ph.D.

E-mail: ratko.stankovic@fpz.hr

KRISTIJAN ROGIĆ, Ph.D.

E-mail: kristijan.rogic@fpz.hr

University of Zagreb

Faculty of Transport and Traffic Sciences

Vukelićeva 4, 10000 Zagreb, Croatia
Transport Logistics

Review

Submitted: July 14, 2014

Approved: Nov. 11, 2014

\title{
POSSIBILITY OF APPLYING BUSINESS PROCESS MANAGEMENT METHODOLOGY IN LOGISTIC PROCESSES OPTIMIZATION
}

\begin{abstract}
Raising the service level and developing new logistic services require better understanding of logistic processes and possibilities of optimization. Different methodologies have been used for that purpose, while the application of Business Process Management (BPM) methodology is outlined in this paper. Identifying parts of logistic processes that could be optimized is facilitated by applying BPM methodology. It also enables more accurate quantification of impacts of the changes introduced in a particular process or activity on the processes as a whole and to other interacting processes. The application of BPM methodology is demonstrated in the case study, where a solution for logistic processes optimization is suggested and the prospective outcomes are simulated. The results of the logistic process comparative analysis have indicated a synergic effect of different improvements in sub-process on the effectiveness of the process as a whole, both on the operative and managerial level. The respective changes in workload distribution among interacting logistic processes have been quantified according to the same methodology.
\end{abstract}

\section{KEY WORDS}

logistic processes; Business Process Management; optimization; logistic process simulation;

\section{INTRODUCTION}

Design and optimization of logistics processes, as fundamental part of logistics system organization, is gaining importance by researchers and practitioners. Processes are generic factors in all organizations, defining what is done and how it is done. Understanding a process can be very difficult, as processes are often considered generally, without detailed analysis.
Analyzing each process separately is less demanding than considering them as parts of a system, with interactions, priorities and resource sharing. Therefore, a large number of factors need to be approximated in order to obtain a complete insight in the system of business activities. For this reason, one of the widely used multi-view frameworks, Architecture of Integrated Information Systems (ARIS), was applied in this research.

Davenport [1], Hammer and Champy [2] define process as a collection of activities that take input of one or more types and create output that has a value for the user, emphasizing the way a job was done, rather than what was produced. Focusing on the business logic (how the job is done), a process becomes a specific sequence of work activities in time and space. It has exact beginning and ending, while inputs and outputs of data flows are clearly defined. Basically, there are three types of business processes [1, 2, 3]:

a) Management Processes - processes that regulate the operation of the system, such as strategic management and corporate governance processes.

b) Core Processes - processes that create a primary value, such as procurement, production, sales, etc.

c) Support Processes - processes that facilitate core processes, such as human resources management, accounting, technical support, etc.

Depending on the company main business, logistic processes can be categorized as core processes (companies that provide logistic services to the market) or support processes. In both cases, logistic processes are a factor of costs, and thus have significant impact on business profitability. Current researches have been dedicated to quantitative improvement, redesign or optimization of business processes, but mostly from 
managerial or IT point of view. However, studies focused on logistic issues of this topic are still in an early stage, more oriented to the process view of the supply chain [4]. The basic hypotheses regarding the logistic processes optimization refer to integration, mutual coordination and smooth flow of information. In order to manage processes in real time, solutions that enable real-time reporting on operative activities are needed (especially on the process drivers). According to the authors $[4,5,6]$, managing processes in real time is possible by establishing direct connection between the process performance, object of measurement and information flow. It enables accurate identification and analysis of deviances in the monitored logistic process. Different methods have been suggested for establishing such connections. Authors mostly apply methods for logistic process reengineering separately for each process, focusing on workflow or information flow $[7,8,9]$. The weakness of such approach refers to inability of quantifying impact of a particular process optimization on the whole system performance.

For this reason, the BPM methodology is applied in this research. It facilitates identifying parts of logistic processes that can be optimized, as well as interactions between processes. It enables evaluating impacts of changes introduced in a particular logistic activity on the whole logistic process and on other interacting processes. Although simulation of logistic processes is not the purpose of this research, simulation experiments (by ARIS simulator module) were used to evaluate improvements in the performance of processes, achieved by optimization.

The paper is structured in five sections. In the first section, the main definitions regarding processes are given, as well as literature review and definitions of the research objectives. The second section outlines the basic definitions and the applied methodology framework. In the third section, the problem of the research is defined, with the results of static and dynamic process analysis. The last section is dedicated to discussion of the results, final conclusions and suggesting the future research issues.

\section{BUSINESS PROCESS MANAGEMENT METHODOLOGY}

Business Process Management (BPM) has been attracting attention of researchers and practitioners for more than a decade and its attention is now shifting from the enactment of business processes towards the improvement of business processes [10]. The most common definition of BPM is: "BPM is the area of knowledge at the intersection between management and information technology, which includes the methods, techniques and tools for design, control and analysis of operational business processes involving hu- mans, organizations, programs, documents and other sources of information" [12]. In terms of management control, BPM is understood as a set of methodologies, techniques and tools that are used to support the analysis and process improvement, while from a technological standpoint, BPM supports business processes using methods, techniques and software tools for design, implementation, control and analysis of operable process [13]. Furthermore, BPM as a holistic way of managing the organization $[10,11]$, is the method for adapting business processes to business strategy, and for optimizing overall performance by improving specific activities within the individual departments or at the corporation level [14]. The BPM supports design, enactment, control, and analysis of business processes [10]. It is used for improving company performance by constant evaluation of the value added in each part of its processes. That is why it is often described as a method of optimization that strives for efficiency and effectiveness by seeking flexibility and integration with technology.

The BPM architecture (Figure 1) should be understood through several layers, each having its depth of observation. The first layer refers to operational level where activities are executed as they are designed (asis state). On this level monitoring and measurement of execution are performed, for controlling purpose. According to controlling data, optimization module is used for searching optimization areas within a process or a network of processes. In this module two kinds of analysis can be done. Static process analysis (static evaluation method) is used to calculate how economical the process execution is in terms of logic of activity, doubled activities and resource used. It does not include parallel process so performance indicators are linearly calculated. Dynamic process analysis (dynamic evaluation method) is done using simulation where activities and resources are tracked during process execution, parallel paths and decisions are taken into account so performance indicators are non-linearly calculated. By this analysis, the impact that optimization of one process has on the other processes can be easily quantified, as well as process execution, waiting times, bottlenecks, throughput times, and weak points. Simulation of processes is performed to determine optimization effects and changes needed in the process design (or re-design). Configuration, customization and generalization of processes are defined in the design module, according to strategy goals. Abstraction of company processes is enabled by this approach, from strategy to execution level, so visibility is increased, as well as consolidation of data needed for daily operation.

The key BPM aspect is the process capacity articulation that involves resources capacity. Further on, process improvement is a continued activity of BPM, while process measurement for process perfor- 


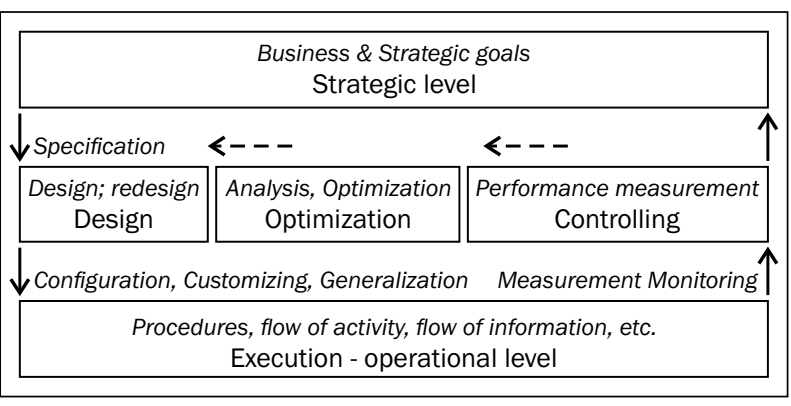

Figure 1 - BPM architecture layers

mance optimization between user requirements and economic objectives, is an integral part of BPM methodologies. BPM is often wrongly considered as an alternative or parallel activity of conducting business process re-engineering (BPR). The difference is that BPM is a methodology for daily use while the BPR is one-off change, i.e. one-time project. Furthermore, it is often considered the same to workflow management. Workflow is a term that describes the automation of the usual human operation, tasks and transactions, and covers the entire spectrum from simple cases to high-intensity flow of transactions. Workflow systems outline manual process [11], and constitute a part of BPM systems.

In process design BPM methodology applies standardized characteristics that must be met by the process, thus achieving exact standards in design. Processes designed in such a way are suitable for interconnection and recognition, and enable easier process integration between different systems. In BPM philosophy process does not end by crossing company limits, but extends towards the end user. Standards set in the process design by BPM accurately define input-output data flow, setting framework for the selection and integration of information systems. Information system built within such framework proved to be a more comprehensive support, than those which are pre-designed.

Abstraction of a process is often expressed by ordered graphs, whereas an Event-driven Process Chain (EPC) is the most commonly used. The EPC is a modelling language, used to describe business processes and workflows. It offers many ways for modelling processes, analyzing them, and identifying improvement potentials. The EPC is an ordered graph of events and functions, and provides various connectors that allowalternative and parallel execution of processes using logical operators, such as $\mathrm{OR}(\mathrm{V})$, AND $(\wedge)$, and XOR $(X)$. A major strength of EPC is its simplicity and easy-to-understand notation, which makes it a widely acceptable technique to denote business processes. Any EPC diagram must start with event(s) and finish with event(s), and can involve several functions. Events are shown by hexagon, while activities are shown by rectangle.
The Event-driven process chains are used in many industries and are supported by different tools. EPCs were as part of ARIS invented back in 1992 by Prof. Scheer from the University of Saarland [14]. Although recent version of ARIS programming tools include simulation module, it has not been widely used in the way outlined in this paper. Simulation of processes designed by applying BPM methodology implies simulating a network of different level process, including resource sharing, workload scheduling, which makes it highly demanding.

\section{CASE STUDY}

The possibilities of applying BPM methodology in optimizing logistic processes are demonstrated in the case study of one automotive and machinery spare parts retailer in Croatia. The company has an international network of suppliers (more than twenty) and is ranked second by market share in Croatia. The company stocks over 56,000 articles, which are distributed to the market via three marketing channels: retail shop, web shop and telephone orders. BPM methodology was applied in optimization of the company logistic processes, through the following steps:

- Collecting information on processes by screening on sight and interviewing the company employees;

- Mapping and basically modelling of the processes as Event-driven Process Chains (EPC) diagrams;

- Verification of the EPC diagrams, including identifying processes interfaces and interactions;

- Static analysis of the processes;

- Defining a solution for optimization;

- Dynamic analysis of the processes;

- Validation of the process models (EPC diagrams);

- Quantification of the optimization outcomes.

By carrying out these steps, optimization areas were identified in the logistic processes, impact of changes introduced in sub-processes on the main process were quantified, as well as impact on other interacting processes.

\subsection{Modelling the logistic processes}

The core business (high-level processes) of the company is based on three main processes: Procurement, Warehousing and Sales. The warehousing process was selected to be outlined in this paper, as it is triggered both by Procurement and by Sales processes, which makes it suitable for the purpose of the case study. The warehouse process was decomposed into three lower level processes (sub-processes) and their activities:

1. Shipment receipt;

2. Storage;

3. Order picking. 
Duration of each activity and probability of branching were determined by on-sight screening, and interviewing employees during the period of one week. Based on the collected information, the processes were modelled as EPC diagrams by using ARIS software. Probability distribution of activity duration was determined according to the chronographic records (time sheets), obtained by on-sight screening. The influence of stochastic variables is also captured in this way.

In EPC diagrams, probabilities of branching (activity activation) are indicated above the connection lines of XOR logic operator (e.g. in Figure 2, probability 0.95 should be understood that $95 \%$ of shipment arrivals activate the unloading palletized goods activity). Events connected with activities via logic operator AND trigger all of them at the same time.

Frequency and schedule of events that trigger processes were determined according to the company records from the last three years. Probability distribution of activity duration is indicated by the above activity (e.g. in Figure 2, execution of the delivery sheet check activity takes 1 minute of time, while execution of the order checking activity takes 3.5 minutes minimum, 10 minutes maximum but most frequently it takes 5 minutes of time). The same notation is followed in EPCs shown in Figure 3 and in Figure 4.

\subsubsection{Shipment receipt process}

This process encompasses activities related to shipment receipt from the carrier (only the number of packages and outside appearance are checked against the waybill). It is triggered by pre-advice of the shipment arrival by the procurement department. Execution of the process starts with the shipment arrival at the company premises and ends when the goods are placed into the receiving area. Activities of this process are executed by a warehouseman, but also involve engagement of the warehouse manager, head of procurement department and the carrier (driver). This process has priority, so all resources required are exempted from other activities, in order to get this process accomplished as soon as possible. EPC diagram of this process is shown in Figure 2.

\subsubsection{Storage process}

Activities of Storage process are related to receipt of the goods by articles, which involve putting the goods to temporary storage location (TSL), checking articles against entry form and positioning the goods at permanent storage location (PSL). It is triggered by placing the shipment into the receiving area. The process starts with generating entry form (in hard copy) and ends when the goods are positioned at the permanent storage location.

Activities of this process are executed by warehouseman, but also involve engagement of the warehouse manager, head of procurement department and the supplier, in case of any discrepancy (the goods do not fully correspond to the entry form). This process has lower priority than the other two main processes; therefore, it is accomplished when the resources are available. EPC diagram of this process is shown in Figure 3.

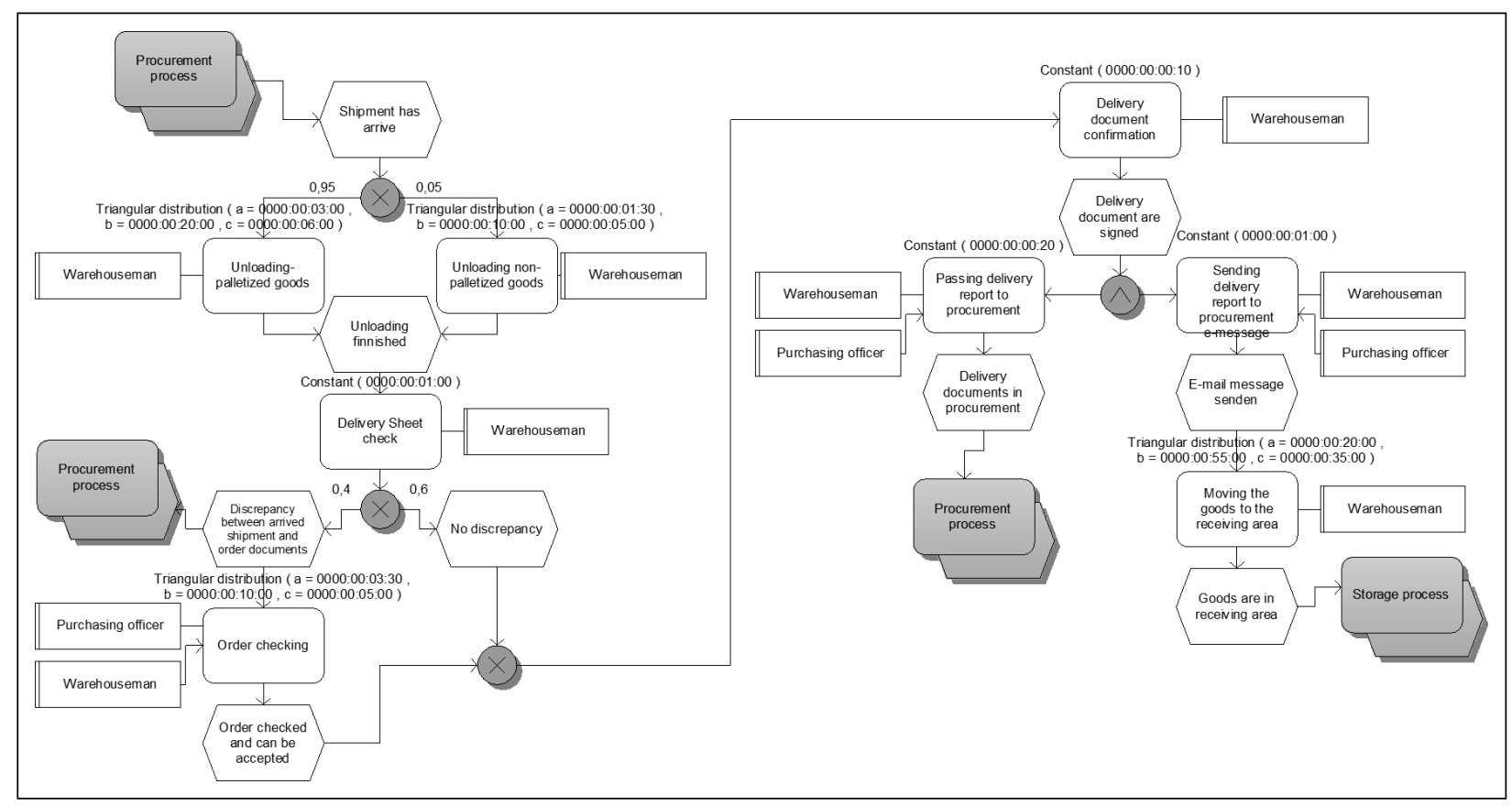

Figure 2 - EPC diagram of Shipment receipt process 


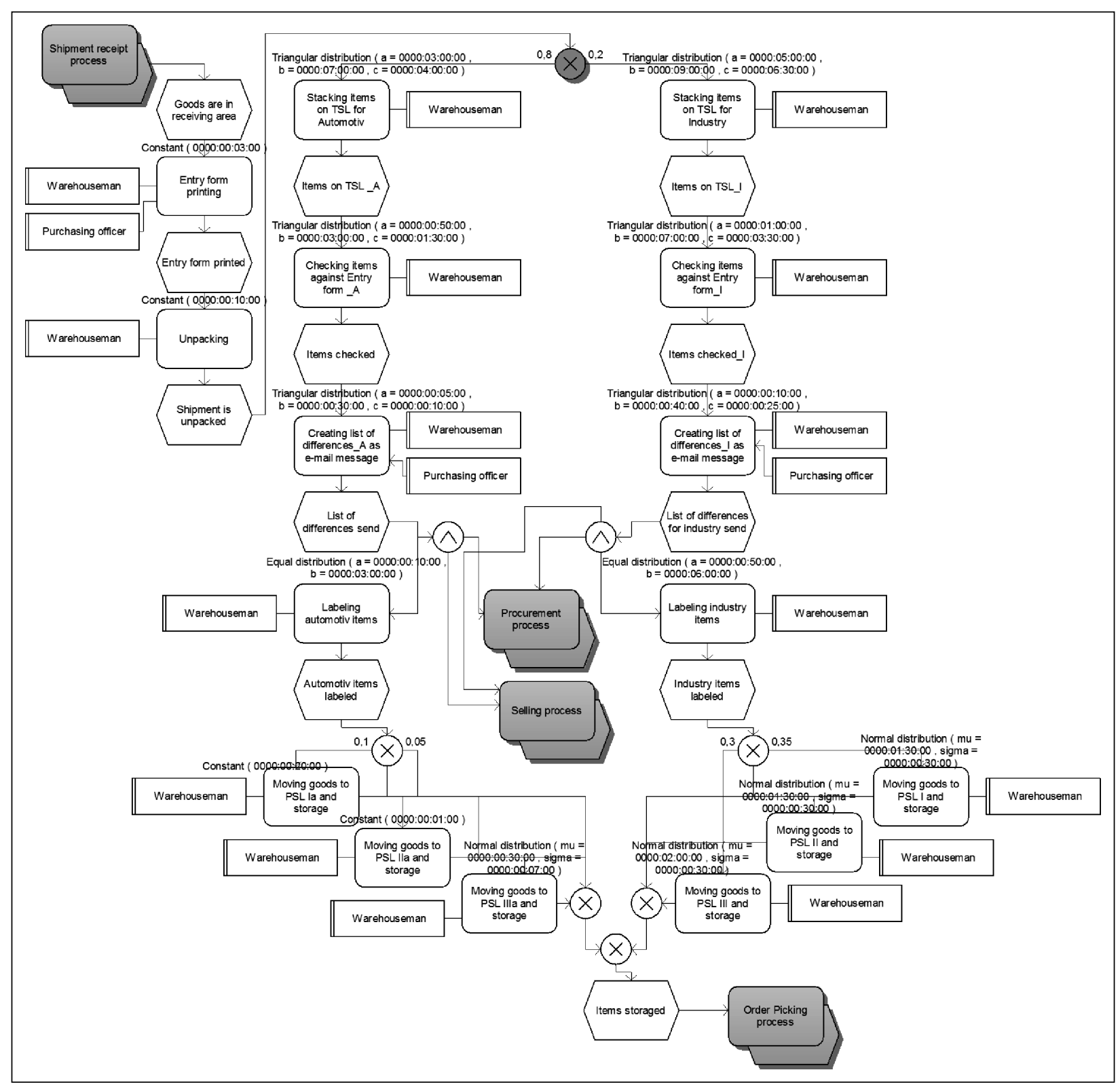

Figure 3 - EPC diagram of Storage process

\subsubsection{Order picking process}

This process consists of activities related to customer order fulfilment. The process is triggered by receiving an order from a customer, through any marketing channel of the company (retail shop, web shop, telephone order). The process starts when the warehouse receives respective picking order, created by the sales department and ends when articles are collected from the PSL and handed over to the salesman or directly to the customer, or placed into the dispatch area to be delivered to the customer.

Activities of this process are executed by salesman and warehouseman. This process has different priority with reference to the marketing channel involved. Retail shop has the highest priority, next are telephone orders and then web shop orders. EPC diagram of this process is shown in Figure 4.

\subsection{Static analysis of the logistic processes}

Verification of the EPC diagrams was carried out in two phases, closely coordinated with the respective person in charge at the company. Within the first phase, end-to-end process design was verified (activities involved, duration, execution logic, branching probability, resource allocation). Verification of the process interfaces and interactions with other processes, as well as verification of information flow, were all done within the second phase. After the EPC diagrams were verified, static analysis was performed for each process separately, in order to identify:

- process hierarchy in process map, 


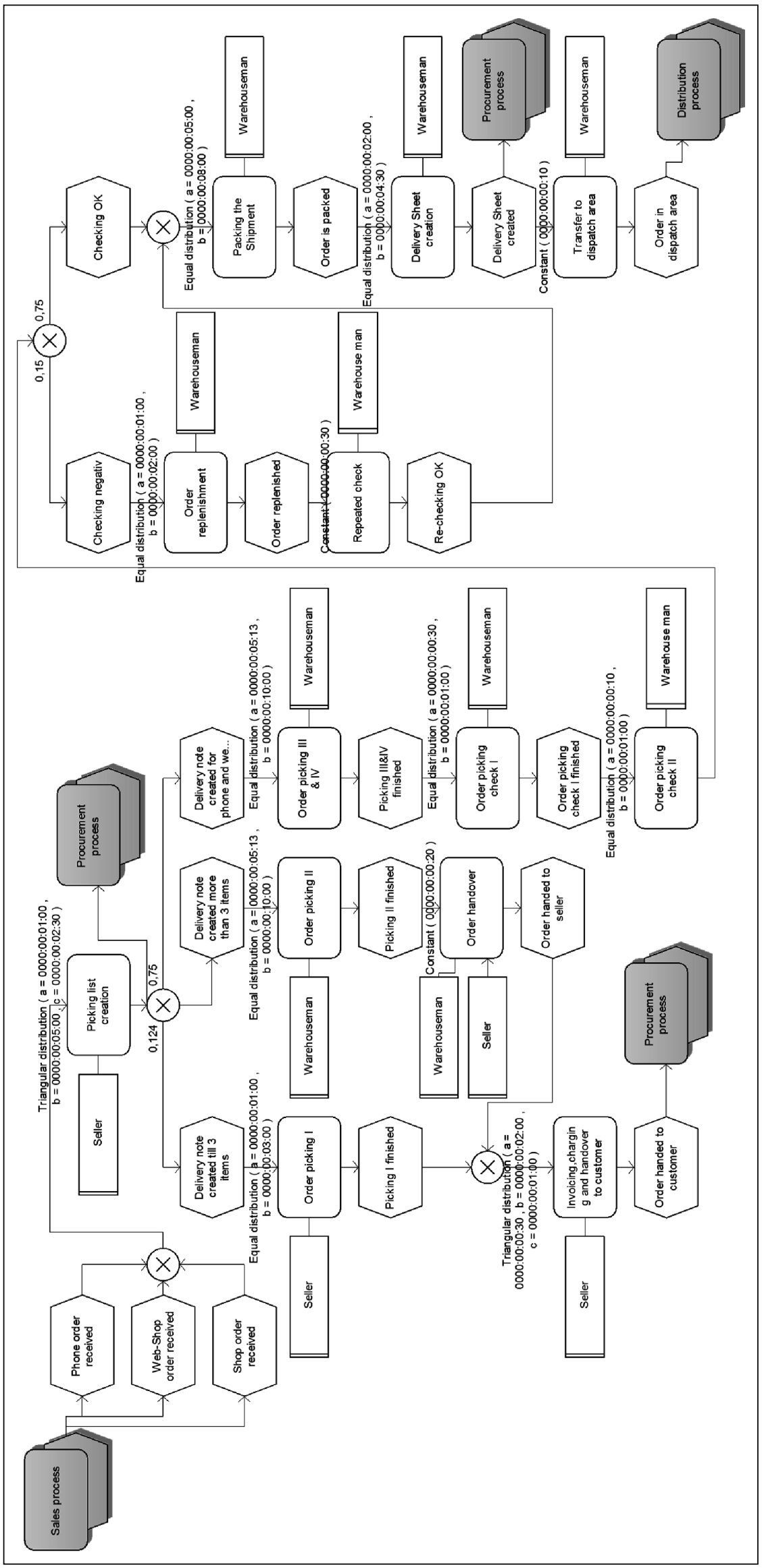

Figure 4 - EPC diagram of Order picking process 
Table 1 - Basic process information

\begin{tabular}{|l|c|c|c||}
\hline & Shipment receipt process & Storage process & Order picking process \\
\hline \hline Number of activities & 8 & 9 & 13 \\
\hline Preceding process & Procurement & Shipment receipt & Storage, Sales \\
\hline Following process & Storage & Picking & Dispatch \\
\hline Trigger & $\begin{array}{c}\text { Pre-advice of the ship- } \\
\text { ment arrival }\end{array}$ & $\begin{array}{c}\text { Placing the shipment } \\
\text { into receiving area }\end{array}$ & Customer order received \\
\hline Interacting process & Procurement & Procurement & Sales \\
\hline Average throughput time & 55 minutes & from 8 to 20 working hours & from 4 to 30 minutes \\
\hline \hline
\end{tabular}

- preceding and following processes,

- process throughput time,

- overlapping and double activities.

\subsubsection{Results of the static analysis}

Basic processes information on the Warehousing main process obtained by the static analysis is outlined in Table 1. Number of activities presented in EPC is listed for each of its processes. The preceding process and the following process show the direction of the main process flow, while trigger indicates the event that activates the process flow. Interacting process is the process triggered by some event of the observed process. The average process throughput time is calculated according to the respective EPC diagram, as a sum of its activities duration, taking into account the probabilities of branching.

The waiting time for activity execution (availability of resources) was neglected. The Procurement process was found to be most interacting by the observed processes (shipment receipt, storage and order picking). For this reason, it was selected for analyzing process workload distribution.

Procurement process workload breakdown against activities was determined by on-sight screening and interviewing employees during the period of one week. It is expressed as average percentage share in total working time, in Figure 5.

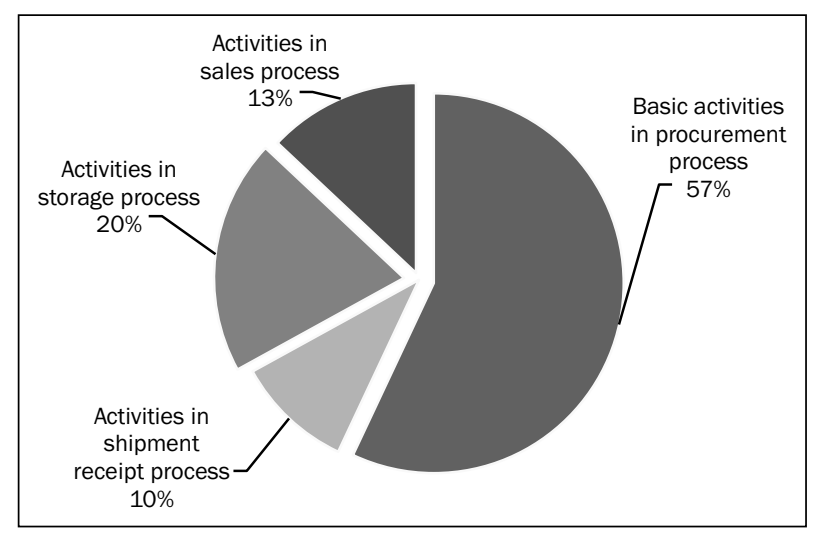

Figure 5 - Procurement process workload breakdown against activities

\subsubsection{Optimization of the Warehousing processes}

Potential optimization areas were found based on identifying activities and events in EPC diagrams that cause needless repeating of operations, information flow disturbances and wasting resources. With reference to the results of the static analysis and the company expectations (a low cost solution with minimal modifications of the processes), the implementation of bar code technology was suggested. The assessment of prospective optimization outcomes was based on EPC diagrams and information provided by the equipment supplier (for demonstration purpose, an average reduction of activities duration by $15 \%$ was adopted where applicable). On the process level, implementation of bar code technology should enable reducing process throughput time as shown in Table 2, while on the activity level it should reduce the duration of certain activities and eliminate certain activities, as shown in Figure 6.

Table 2 - Process throughput time reduction by implementing bar code technology

\begin{tabular}{||l|l|c||}
\hline \hline & \multicolumn{1}{|c|}{ Process } & $\begin{array}{c}\text { Reduction of the } \\
\text { process throughput time }\end{array}$ \\
\hline \hline 1. & Shipment receipt & $\begin{array}{c}16 \% \text {, regardless of the } \\
\text { number of resources }\end{array}$ \\
\hline 2. & Storage & $\begin{array}{c}16 \% \text { to } 30 \% \text {, depending on } \\
\text { the number of resources }\end{array}$ \\
\hline 3. & Order picking & $\begin{array}{c}25 \% \text { to } 33 \% \text {, depending on } \\
\text { the number or resources }\end{array}$ \\
\hline
\end{tabular}

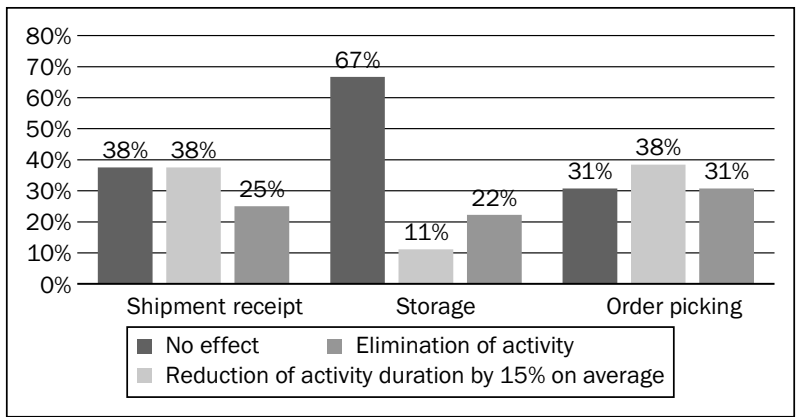

Figure 6 - Optimization outcomes breakdown per processes 


\subsection{Dynamic analysis of the logistic processes}

For the purpose of dynamic analysis, the company daily operations were simulated for one-month period, which was performed by using ARIS simulation module, based on the EPC diagrams. Two scenarios (simulation experiment) were simulated:

1. Each process was simulated separately, in order to validate process models.

2. All three processes were simulated simultaneously, in order to determine the time distribution within the processes, taking into account the priorities in execution and resource sharing (resource availability).

Each scenario was simulated without barcode technology implemented and with barcode technology implemented, to quantify the optimization outcomes.

\subsection{Results of dynamic analysis}

The results of the first scenario simulation corresponded with the results of the static analysis, except of Order Picking process, where waiting time appeared. Results of the second scenario simulation are more important for this research, as they represent a real life situation, where activities are carried out simultaneously, have different priorities, share the same resources, and wait for resource availability. The results are given in Table 3 and in Table 4.

Average times in Table 3 indicate durations of lower level process separately (Shipment receipt, Storage, Order picking), as well as duration of the Warehousing process as a whole. The average duration time of the Warehousing process is not equal to the sum of the particular processes average duration times due to overlapping (lower level processes partly run simultaneously, one being triggered independently of others).
Results of one-month simulation, based on the company working schedule and average daily workload are shown in Table 4. The shipment receipt process has the highest priority, so all resources are diverted to this process. Storage process is triggered by finishing the shipment receipt process.

For instance, at "No Barcode" scenario, all four shipments are processed in the Shipment receipt process; however, only three of them enter the Storage process and only one of them gets fully processed by the end of regular working hours. It actually means that all four shipments are taken over from the carrier and put into the receipt area. Three shipments are shifted forward to the Storage process, while one shipment remains in the receipt area, waiting for respective resource to become available. The three shipments that entered the Storage process are moved to the warehouse, but only one of them is positioned at permanent location. Such outcome is a result of dynamic resource allocation, where shared resources (warehousemen) are available to lower priority process (Storage) only during the

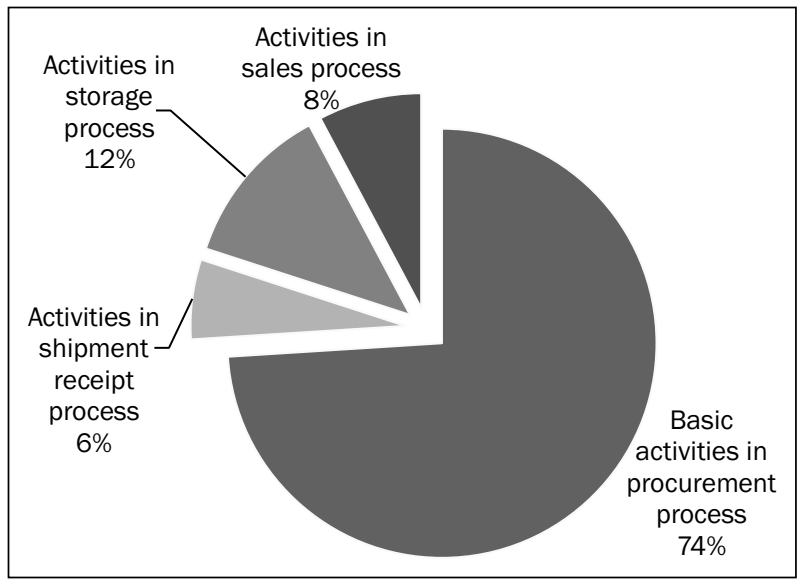

Figure 7 - Procurement process workload breakdown per activities

Table 3 - Distribution of time indicators

\begin{tabular}{||l|c|c|c|c|c|c|c||}
\hline \multirow{2}{*}{\multicolumn{1}{|c|}{ Process }} & \multicolumn{2}{|c|}{ Average throughput time } & Average processing time & \multicolumn{3}{c||}{ Average waiting time } \\
\cline { 2 - 9 } & No barcode & Barcode & No barcode & Barcode & No barcode & Barcode & Reduction \\
\hline \hline Shipment receipt & $00: 57: 57$ & $00: 47: 15$ & $00: 56: 12$ & $00: 45: 30$ & $00: 01: 45$ & $00: 01: 45$ & $0 \%$ \\
\hline Storage & $09: 30: 18$ & $07: 50: 28$ & $08: 12: 15$ & $06: 35: 39$ & $01: 18: 03$ & $01: 14: 49$ & $4 \%$ \\
\hline Order picking & $00: 35: 55$ & $00: 25: 30$ & $00: 22: 51$ & $00: 14: 15$ & $00: 13: 04$ & $00: 11: 15$ & $14 \%$ \\
\hline Warehousing as a whole & $10: 03: 10$ & $7: 53: 56$ & $8: 35: 09$ & $6: 56: 37$ & $1: 28: 01$ & $0: 57: 19$ & $35 \%$ \\
\hline \hline
\end{tabular}

Table 4 - Performance of the processes at average daily workload

\begin{tabular}{|c|c|c|c|c|c|c|c|}
\hline \multirow{2}{*}{ Process (entity) } & \multicolumn{2}{|c|}{ No Barcode } & \multirow{2}{*}{ 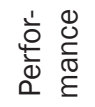 } & \multicolumn{2}{|c|}{ Barcode } & \multirow{2}{*}{ 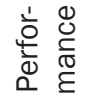 } & \multirow{2}{*}{$\begin{array}{l}\text { Improvement of } \\
\text { performance }\end{array}$} \\
\hline & Entry & Done & & Entry & Done & & \\
\hline Shipment receipt & 4 shipments & 4 shipments & $100 \%$ & 4 shipments & 4 shipments & $100 \%$ & $0 \%$ \\
\hline Storage & 3 shipments & 1 shipment & $33 \%$ & 4 shipments & 2 shipments & $50 \%$ & $17 \%$ \\
\hline Order picking & 2,688 entries & 1,636 entries & $61 \%$ & 2,688 entries & 1,999 entries & $74 \%$ & $14 \%$ \\
\hline
\end{tabular}


periods when not needed by high priority processes (Shipment receipt and Order picking).

Procurement process workload breakdown per activities upon adopting barcode technology (simulation of the second scenario), expressed as average percentage share in total working time is shown in Figure 7.

\section{DISCUSSION}

Results of the analyses performed within the case study according to the BPM methodology are discussed in this chapter. The comparison of data outlined in Figure 5 and in Figure 7 indicates the impact of implementing barcode technology in Warehousing processes on the workload allocation in Procurement process. The involvement of Procurement process resources (purchasing officers) in other process activities was reduced by $4 \%$ in Shipment receipt process, by $8 \%$ in Storage process and by $5 \%$ in Sales process, which would release $17 \%$ of total working time to be allocated on activities of Procurement process. Hereby, the impact of the logistic process optimization on other interacting processes was quantified.

The basic process information (Table 1) and respective EPC diagrams (Figures 2, 3 and 4) are generated by static analysis of the processes and screening on sight. As input variables (shipments, customer orders) differ in quantity and structure, the duration time of each activity was determined by statistical analysis of the collected data. The distribution of each activity duration time is shown in EPCs.

In static analysis, the process throughput time is equal to the processing time, as waiting times (availability of resources) are not considered. Waiting times are calculated in the dynamic analysis where allocation of resources and workload with different priorities are taken into account. In running simulation experiments, the effects of implemented changes in processes are evaluated, both for the lower and for the high level processes.

Outcomes of the logistic processes optimization in terms of effectiveness and performance were determined based on the dynamic analysis results. The results outlined in Table 3 indicate different levels of improvements in sub-process effectiveness, which had a synergic effect on the main process as a whole. For instance, the average waiting time of Warehousing process as a whole was reduced by $35 \%$, which is greater than the sum of particular reductions of waiting times in its sub-processes $(0 \%$ in Shipment receipt process, $4 \%$ in Storage process and 14\% in Order picking process). Implementing barcode technology also affected the performance of each process differently: no effect on Shipment receipt process, Storage pro- cess improved by $17 \%$ and Order picking process improved by $14 \%$ (Table 4 ).

The presented results confirm the applicability of the BPM methodology in logistic process optimization, as well as its advantages with respect to the previous studies. The analysis and modelling of logistic processes based on this methodology facilitate the identification of optimization areas in the processes, quantifying process performance according to different criteria (resource allocation, workload distribution, etc.), as well as impact of changes introduced in a particular logistic activity on the whole process and on other interacting processes.

\section{CONCLUSION}

The design as well as optimization of a logistic process implies that it is considered to be a part of the system, where the optimum of the whole is not necessarily a sum of particular optimums of its parts. This paper outlines the possibility of applying the Business Process Management (BPM) methodology in logistic process analysis, in order to identify which part(s) of the process could be optimized with reference to the total outcome, on operations and management level. BPM methodology also improves transparency of the process decomposition, thus enabling more accurate quantification of impacts of the changes introduced in a particular activity on the process as a whole and on other interacting processes.

A case study of one Croatian retail company in automotive sector was carried out in order to demonstrate the application of BPM methodology in optimizing logistic processes and quantifying the impact on other interacting processes. The input data were collected by screening the current logistic processes of the company and by the use of ARIS simulation module for generating prospective outcomes of changes introduced by the optimization. The results of the logistic processes comparative analysis, facilitated by applying BPM methodology, indicated different level of improvements in sub-process effectiveness, which had a synergic effect on the main process as a whole. BPM methodology also enabled quantifying impact of the logistic process optimization on other interacting processes, both on operations and management levels.

In terms of practical application, BPM methodology has certain weaknesses, which mainly refer to the development level of IT system and its adjustability. In order to benefit from BPM methodology advantages, continuous monitoring of the processes performance is required, which involves generating, collecting, processing and distributing a large quantity of data, mostly in real time. It makes implementation of BPM methodology hardly possible in cases where IT system 
is not sophisticated enough to fully meet these requirements. For this reason, many companies may not be able to adopt this methodology, although it could improve their business.

Further research could be focused on the possibilities of implementing BPM methodology on a company level, to encompass the supporting processes and management processes. With reference to that, the criteria for selecting key activities for monitoring the process performance could be defined, which would enhance the benefits of implementing BPM methodology.

\section{Dr. Sc. DIANA BOŽIĆ}

E-mail: diana.bozic@fpz.hr

Dr. Sc. RATKO STANKOVIĆ

E-mail: ratko.stankovic@fpz.hr

Dr. SC. KRISTIJAN ROGIĆ

E-mail: kristijan.rogic@fpz.hr

Sveučilište u Zagrebu, Fakultet prometnih znanosti

Vukelićeva 4, 10000 Zagreb, Hrvatska

\section{SAŽETAK}

\section{MOGUĆNOST PRIMJENE METODOLOGIJE UPRAVLJANJA POSLOVNIM PROCESIMA U OPTIMIZACIJI LOGISTIČKIH PROCESA}

Podizanje razine usluga i razvoj novih logističkih usluga zahtijevaju bolje razumijevanje logističkih procesa i mogućnosti za njihovu optimizaciju. U tu svrhu koriste se različite metode, a u ovom su radu prikazane mogućnosti primjene Business Process Management (BPM) metoda. Primjenom BPM metoda olakšano je identificiranje dijelova logističkih procesa koji mogu biti optimizirani, te je omogućena preciznija kvantifikacija utjecaja promjena uvedenih na određenoj razini procesa ili aktivnosti, na procese $u$ cjelini, kao i na druge procese $u$ interakciji. Primjena BPM metoda prikazana je u studiji slučaja, gdje je predloženo rješenje za optimizaciju logističkih procesa, te je temeljem rezultata simulacije provedena analiza učinaka predložene optimizacije. Rezultati komparativne analize logističkih procesa pokazali su sinergijski učinak ostvarenih poboljšanja podprocesa na učinkovitost procesa u cjelini, kako na operativnoj tako i na upravljačkoj razini. Odnosne promjene $u$ razdiobi radnog opterećenja logističkih procesa u interakciji, kvantificirane su istim metodama.

\section{KLUČNE RIJEČI}

logistički procesi; upravljanje poslovnim procesima; optimizacija; simulacija logističkih procesa;

\section{REFERENCE}

[1] Davenport T. Process Innovation- Reengineering work through information technology. Boston: Harvard Business School Press; 1993.

[2] Hammer M, Champy J. Reengineering the Corporation: A Manifesto for Business Revolution. Harper Business; 1993.

[3] Dreiling A, Rosemann M, Aalst WMP, Sadiq W. From conceptual process models to running systems: $A$ holistic approach for the configuration of enterprise system processes. Decision Support Systems No.45, 2008; p. 189-207.

[4] Milleta PA, Schmitt P, Botta-Genoulaz V. The SCOR model for the alignment of business processes and information systems. Enterprise Information Systems. 2009;3(4):393-407.

[5] Romano P. Co-ordination and integration mechanisms to manage logistics processes across supply networks. Journal of Purchasing\&Supply Management. 2003;9:119-134.

[6] Gudehus T, Kotzab H. Comprehensive Logistics. Hamburg: Springer; 2009.

[7] Čičin-Šain M, Vukmirović S, Čapko Z. Methodological Framework of Business Reengineering within Logistics System. Journal of Computing and Information Technology - CIT. 2004;12(2):83-93.

[8] Chien-wen, S., Ching-Chih, C.: Business process re-engineering in the logistics industry: a study of implementation, success factors, and performance. Enterprise Information Systems. 2010;4(1):61-78.

[9] Pašagić Škrinjar J, Rogić K, Stanković R. Location of Urban Logistic Terminals as Hub Location Problem. Promet - Traffic\&Transportation. 2012;24(5):433440.

[10] Vom Brocke J, Rosemann M. Handbook on Business Process Management: Strategic Alignment, Governance, People and Culture. Berlin: Springer; 2010.

[11] O Connell J, Pyke J, Whitehead R. Mastering your organizations processes. Cambridge: Cambridge University Press; 2006.

[12] Shtub A, Karni R. ERP-The dynamics of supply chain and process management. London: Springer Science\& Business Media; 2010.

[13] Wang M, Wang H. From process logic to business logic - A cognitive approach to business process management. Information\&Management. 2006;43(2):179193.

[14] Smart PA, Maddern H, Maull RS. Understanding Business Process Management. British Journal of Management. 2009;20:491-507. 